\title{
Forest Vegetation Management and The Politics of Environment ${ }^{1}$
}

\author{
by Mike Halleran ${ }^{2}$
}

\section{Abstract}

Traditionally, resource management was regarded mainly as a technical challenge. With the upwelling of environmental concern, questions of a social nature now dominate much resource management discussion. In future, implementation of even tested and proven resource techniques may be disallowed due to organized public opposition - regardless of whether they happen to work or not.

\section{Résumé}

On considérait l'aménagement des ressources traditionellement comme un défi d'ordre technique. Le redoublement de soucis environnementaux a entrainé des questions d'ordre social qui dominent maintenant beaucoup des discussions au sujet de l'aménagement des ressources. Au futur, la mise en oeuvre même des techniques éprouvées pour les ressources ne peut pas être admis à cause de la résistance publique organisée, si ces techniques sont effectives ou non.
Traditionally, resource management was regarded as mainly a technical challenge. With the upwelling of environmental concern, questions of a social nature now dominate much resource management discussion. In future, implementation of even tested and proven resource techniques may be disallowed due to organized public opposition - regardless of whether they happen to work or not.

For example, if there is a sufficient opposition to clearcutting it could very well cease. The evidence that clearcutting is ecologically appropriate on some sites and for some forests may be irrelevant. This is not a technical question likely to be decided on the evidence. If "beauty is in the eye of the beholder" the same might apply to "ugly". There are quite obviously more people who believe clearcuts are ugly than believe them beautiful. In parts of British Columbia, green stop signs are appearing on lawns and other prominent locations. They say "STOP Clearcuts". A smaller second message says "log for the future" obviously intended to leave the impression that after clearcutting a site, no future logging can occur. The same sort of thing could happen with forest chemicals. Domestic use of pesticides and herbicides is three times larger than the amount used in forestry - according to Agriculture Canada. And their use by farmers is many times greater than the forest and domestic use combined. For some reason, there are people who raise militant protest about the use of herbicides in forestry but their use in agriculture is not much protested, if at all. Why is the most minimal use singled out for attack and the larger ones (largely) ignored? Perhaps it is because herbicide use in the forest is just one more thing that people dislike about industrial forestry. Like slash fires and dirty creeks, herbicide use is seen as an environmental negative from which "someone else" derives benefit.

I think the distinction may be an important one. We all require food to live and few of us can grow, hunt or gather our own. People might be opposed to the use of agricultural chemicals but without them we would not eat or eat less. And around the home they keep the lawn green and weed-free. Meanwhile, forest chemicals are seen as something that makes money for forest companies and makes trees mature

\footnotetext{
"Paper presented at the Joint Technical Session, "Vegetation management problem or challenge," of the Forest Ecology, Forest Pest Management, and Silviculture and Tree Improvement Working Groups at the CIF/FC Annual Meeting, Kananaskis, Alberta, October 1989.
}

${ }^{2}$ Natural resources journalist and broadcaster, Kaslo, B.C. in 50 years instead of 75 years. Many people in the "now" generation might say "so what" to that. For some, stopping the use of herbicides today would be much more important than growing "trees for tomorrow".

The fact that our whole economy benefits from logging and the sale of forest products is not automatically understood by our largely urban population. Forestry is still the biggest job-creator in the country and is likely to remain so for many years to come. (British Columbia is by far the most important forest province in Canada and forestry in British Columbia is what wheat is to Saskatchewan. Over 80 thousand jobs are directly tied to forestry in B.C. according to Statistics Canada. At least three times that number are created in the support areas, according to the $\mathrm{BC}$ forest industry. Well over $50 \%$ of B.C.'s exports are in the form of forest products).

We need evidence-based breakdowns on what portions of the economy, not just jobs, provisions for schools, hospitals, etc., are created by such activities as logging, tourism, and other sectors. I would like to be very sure that the numbers are not being exaggerated - not counted twice - that sort of thing. I think this kind of data would make it easier for people to compare one set of choices with others. But alas, controversial social or environmental questions are seldom decided on the evidence, a fact of concern to forest scientists. The politics of environment continues to play an ever-larger role in resources questions and the technical side comes to matter less and less. A lot of the discussion between sectors sounds like "my dad can lick your dad".

The forest sector has recently come under sharp attack for some of the environmental consequences of its actions. Some of that criticism was totally justified - even overdue. Much is based on the fact that most people know very little about logging or forestry and a small amount of this criticism is probably the result of deliberate anti-logging propaganda. Every aspect of forestry is in disrepute today and to a great extent, much of this lost image may have resulted from selfinflicted wounds. It is regretable that the forest sector did not set out to explain its work to the public until many in the public sector had already made up their minds. The only really successful P.R. program was Smoky the Bear and it may have backfired (please pardon the pun) for many people seem to believe that logging is hard on the environment while forest 
fires only affect industry profits which many people believe are too high anyway.

In the past year, I have had people draw my attention to two stark-looking landscapes as evidence of the destruction of logging. But neither had ever been logged. One was a huge burn; the other, the drawn-down reservoir of the Revelstoke dam. But the forest sector got the blame for them. In B.C. credibility worsened with the centralization of the Forest Service in which most community ranger stations were closed. The forest service used to be part of the community and when that ended, suspicion and mistrust replaced it. The Forest Service is under attack from all sides. In B.C. it is variously accused of allowing both undercutting and overcutting; of leaving too much habitat for fish and wildlife as well as not enough; of not providing enough parks and wilderness as well as too much and so on.

So polarized is the debate becoming that some environmental activists have taken to tree-spiking and other vandalism. One spiker brags at having "saved" thousands of trees. Examples of class-based stereotyping are becoming quite common. Loggers and foresters are seen as people in the business of altering environments to suit their own special interest and they are also accused of lacking any personal or emotional commitments to the forest itself, even though by career and lifestyle choice, they have decided to spend their lives in the forest.

The connection between resource extraction and community stability is little understood, probably because most people live in large cities where resources are not present. In Alberta large economic benefits are still derived from grain farming. I do not know of any campaigns against it but one could point to many things about grain growing that are environmentally and esthetically questionable. The soil storms of the 'thirties were as much man-induced as natural. As global warming continues we might see their like again. This is without real counterpart in forestry. It is true that some plantations have been disappointments and steep-slope logging has caused serious soil erosion but I know the standard continues to improve.

Clearcutting does not prevent new forests. Not even huge fires can do that for long. The conifers emerge again. It may even be unwise to speed up the process too much. My ecologist friends tell me that allowing a forest to pass through the succession of annuals, brush species and deciduous trees may be best on some sites. The conifers will certainly come back; indeed, it would be almost impossible to stop them. The exclusion of fire has caused the takeover of thousands of acres of interior grassland (it is now forest). Overgrazing occurs on the (shrinking) remainder.

Much is said about the impact of forestry on wildlife. Not all of it is true. Some species are affected adversely. Others benefit. Species diversity may change. Overall, negative impacts on wildlife are the inevitable result of ever-rising human numbers who produce ever-rising demands on the land. In B.C., one saving grace may be that commercial forests only occupy $30 \%$ of the land area and on the remaining $70 \%$ we have done no logging at all - nor are we likely to.

For 20 years, my work as a film maker and reporter of resource and outdoor topics has taken me to every corner of B.C. For sure, I have seen an enormous improvement in all aspects of resource management over that time. I believe the B.C. environmental crisis is real but overstated.
Of course forestry destroys wilderness as does any kind of intensified human presence regardless of purpose. Agriculture, hydro, urban expansion, even parks can destroy wilderness. The debate over whether to have more areas exempted from forestry needs to go foreward. (A little more calmly if you please.) But however it ends, one would hope that the decisions are made on the evidence, following consideration of the benefits and costs of the various choices. Wilderness is a desirable social value and we must have it, but it is not free. There are trade-offs here.

When I began producing resources documentaries for $\mathrm{CBC}$ in the late 'sixties, there was little public interest. And CBC management referred to environment as "a fad". Some fad. (The only reason I have to offer is that most of them came from Toronto.) In spite of them, I produced dozens of programs looking at overgrazing, overfishing, the need for more reforestation, more parks, better consideration for fish and wildlife and, in my view, the most vital land use item of all: the loss of hundreds of miles of scarce valley bottom to the single use of hydro reservoir-building. In 1977 I quit my job at CBC to campaign against the plan to dam the McGregor River (a Fraser tributary) and divert it into the Peace River, a tributary of the Mackenzie. This linking of Pacific and Arctic watersheds would have drowned extensive forests and wildlife habitat and posed a severe threat to Fraser River salmon.

My wife Jeanne joined me on the campaign. We sacrificed 10 years of employment benefits and security to campaign against this hydro project. In one three-month period, we held over 70 public meetings each in a different town. The project was finally shelved by hydro but is now being dusted off again. Considering that public and press are now pre-occupied with other issues, hydro might just get it built this time. I regard this as a kind of test, to see whether the current generation of environmental activists can differentiate between environmental changes of a temporary nature (such as may occur after logging) and the permanent application of single use such as occurs with hydro. BC's salmon rivers are threatened again.

You people will not be unaffected by such questions. One of your interests is to devise means of growing more wood on less ground. Unless I am very wrong, there is going to be less ground on which to grow trees and society may need your skills more than ever. First, you have some selling to do. Many of your techniques are in disrepute. People think that much of what you do involves some quite nasty chemicals and that you think of the "ideal" forest as resembling some kind of coniferous cornfield. You have to persuade the cynics and they are legion.

Physical evidence is starting to show up. Just north of Campbell River on Vancouver Island, a large sign notes that a forest site was logged in 1919 and again in 1988. We still have many unsolved problems in forestry and pointing out the more obvious ones has almost become a profession. But despite the critics, there is real proof that previously logged forests are coming back and some are being harvested now. Despite the recent reports of failed planting experiments reforestation works. Problems? You bet! Need for improved management? Absolutely! But a failure? Nonsense.

British Columbia, like other places, faces a "falldown effect" - a shortage of timber supply as we make the transition from first to second pass. No attempt has been made to conceal this - in fact, it was announced publicly some 10 years ago. Just how much of a falldown does occur will 
depend largely on how intensively we manage over the next decade or two, a process in which many of you will no doubt be involved.

That piece of second-pass logging has been planted back but the original patch was never planted or even "managed" in the strict sense of the term. It was logged and left to regenerate on its own like hundreds of thousands of hectares everywhere. Modern forestry critics (including some foresters) suggest that every logged hectare must be planted back. The forest sector is often criticized for not doing that, apparently in the belief that if man does not plant them, trees will not grow. Where it suits we should replant. Where it doesn't suit we should not. That should be a technical not a lobby decision.

The current environmental uprising seems to be driving factions farther apart instead of closer together as must occur. Madame Bruntdland stressed that controlling environmental decline will require the efforts of every sector of the community - industry included. In the hinterland I have seen heartwarming examples of cooperation and trust between factions, but the big city environmental groups seem to work at a higher political level without much on-site presence. (I discount demonstrations staged for television.) Polarization is often replaced with trust when all sides get out on the site and kick the dirt around. The presence of media is often anathema to consensus. Resource management by media usually benefits media more than resources.

I have no quarrel with any citizen who gives up family time, business and recreation opportunities, even economic security - to work for a better environment. I've been there. But some of the tactics are deplorable. Very often, these take the form of a vicious, personal attack - very often based on hearsay and seldom preceded by any detailed investigation of the evidence. In some cases, people with any industry connection whatever are simply written off - often publicly. Some of the brightests and best scientific and organizational talent works for industry and it is nothing short of silly to shut it out.

Of one thing I am certain. Without willing industry involvement, the non-industry environmentalists will fail. The citizen groups must know they can never achieve environmental balance on their own. My own personal commitment to resource conservation and a healthy environment is life-long. Failure, regardless of reasons, is unacceptable to me. Besides, I have promised my grandsons a better world and I intend to work to that end. I believe there is still a good chance for consensus. The first thing we need is for all interests to identifiy their most moderate spokespeople: leaders with a talent for statesmanship and good listening skills. Purge the radicals.

Both sides are consuming their energy by adding to the debate with more expensive or outrageous lobby campaigns. It just isn't working. The factions are farther apart than ever. I know that forest sector people are now deliberately avoiding any contact with some environmentalists because it appears that non-stop abuse will be the result. A quite unproductive backlash may be developing, bad for both sides and for the environment too.

As working professionals, much of what you do may become part of mainstream forest management in Canada. In addition to the technical stuff, you must also find ways to bridge the gap between activists and the professions of forestry. You might begin by suggesting to environmental campaigners in your own area that you both need each other. The public must name its priorities and decide what they want from resources, but you people must put that together and make it work. "New" forestry is coming and its creation must be a blend of public expression and real forest science. Facing challenges like the greenhouse effect will also require joint effort - science, industry and public. Continued fortressbuilding (by any faction) is irresponsible.

The public is cynical of all kinds of bureaucracy when it comes to environment - especially cynical of managerclient relations such as: forest service and forest companies, wildlife service and guides or hunters, etc. No sector is exempt from this new criticism. Absence of public protest for given techniques can not be regarded as approval if the public does not know they are happening. All sectors are equally vulnerable. For example, poisoning predators to maximize resource production is more and more deplored by the public who are becoming aware that all sectors (fish, forest and wildlife) use chemicals to kill some "unwanted" species and maximize "desirable" ones.

For decades, the forest sector set the stage for this great groundswell of opposition by mistaking public silence for popularity. Others sectors have done no better. One result has been that the whole concept of "resource management" is now in disrepute. Many people seem to believe that resource management's purpose is to please hunters, loggers and fishermen, those who directly use or harvest resources. The original, lofty, concept of applying scientific resource management to benefit the resources and the people who own them is not believed today. Resources management itself, as a public process, is in disrepute and not just for one resource but for all.

When the faults and shortcomings of resource management are pointed out by responsible citizen groups you should acknowledge these and vow to change. But you must defend the craft itself. NO disciplines (or agencies) can assume that their programs must have public support just because they are not under attack at the moment. You can run, but you can't hide.

All disciplines must join forces to protect the concept of resource management by science instead of management by lobby no matter what its cause.

I apologize for taking such liberties with the vegetation management theme, but in truth, I know very little about forest vegetation management. It seems to me that just about everything you do out there is vegetation management in some way. I expect that how well you succeed will depend on what success you have in first winning public support for your programs. I wish you well. 